\title{
NEW TRENDS IN POULTRY NUTRITION ${ }^{1}$
}

\author{
R. Cmiljanić, Zlatica Pavlovski, Snežana Trenkovski, M. Lukić
}

Contents: Changes in systems of poultry housing, transfer from cage to alternative systems demand certain changes in system of poultry nutrition. Needs for different nutritious matters - primarily in energy since more energy is used in alternative systems, are also changing. On the other hand, EU certain regulations such as prohibition of antibiotics as growth promoters, ban on use of bone and meat-bone meal in poultry nutrition demand new alternative solutions. Today, probiotics, phytobiotics and mixtures of different organic acids are used as growth promoters. Instead of animal protein feeds in poultry nutrition plant protein feeds are used with supplementation of synthetic amino acids. In this way "safe" food for human nutrition is obtained and this production is more economically efficient. In order to improve the utilization of nutritious matters from certain coarse feeds (cereals, sunflower meal, etc.) exterior enzymes are added to diets for poultry to achieve better digestibility of non-starch polysaccharides, some minerals and proteins and at the same time reduce the pollution of the environment. In poultry nutrition today much attention is directed to digestible amino acids and less to digestible proteins. When formulating the diet it is better to use data on digestible amino acids since in this way need of poultry for this nutritious matter is fully satisfied. Also, in modern poultry nutrition micro elements in chelate form are used instead of mineral forms. Mixtures in pellets are used since better production results are achieved, lower mortality and often better quality of the product (meat and eggs). This indicates that in future poultry nutrition should be adjusted to consumer demands. Consumer is becoming more aware of the quality of poultry products.

Key words: antibiotics, enzymes, breeding, nutrition, probiotics, systems, poultry.

\section{Introduction}

New recommendations and regulations of European Union relating to poultry housing systems, quality of feeds and additives used in nutrition impose the need to find alternative solutions. Main objective of mentioned regulations is improvement of housing conditions in poultry breeding, "animal welfare" and providing of "safe" food (meat and eggs) for human consumption. Ban on use of meat and meat-bone meal in poultry nutrition from December 2000 has imposed need to find alternative solution. Previous research has shown that yeast and soybean meal with addition of synthetic methionine and organic selenium can successfully replace animal feeds in diets for poultry (Subrata et al. 1997., Vlahović et al. 1998). Since June 1 st 2000 use of antibiotics as growth promoters in poultry nutrition is prohibited (Bedford 2000, Cmiljanić et al. 2002). Mentioned ban has caused lower production results in "industrial" poultry production. Lower production results in "industrial" poultry production were attempted to be solved by applying alternative solutions - antibiotic replacers such as: probiotics, prebiotics, phytobiotics and organic acids. Results of previous research have shown that mentioned replacers of antibiotics demonstrated positive results in gain of body mass, feed conversion and health condition of poultry (Cmiljanić et al. 2001, Sirvydis et al. 2003). Quality of mentioned replacers is being constantly improved and this will give even better results. From the fifties of the last century enzymes are applied as additives in diets for poultry. Today, enzymes in many European countries are regular additives to mixtures used in poultry nutrition. Addition of enzymes to diets in poultry nutrition improves the digestibility and absorption of nutritious matters and as a result of this better production results are realized and quality of poultry products is improved (Cmiljanić et al. 1999., Supić et al. 1999). New trends in poultry nutrition should provide/ensure the quality of poultry products (poultry meat and eggs). Poultry production has to adjust to demands of consumers. In this paper, a review of new trends in poultry nutrition is presented.

1 Review paper supported by the Ministry of Science and Environment Protection, Project no. TR6885B - Revijalni rad je finansiran od strane Ministarstva za nauku i zaštitu životne sredine Projektom broj: TR6885B

2 Dr Ratimir Cmiljanić - scientific counselor, Dr Zlatica Pavlovski - scientific counselor, Snežana Trenkovski, grad. pharm., Mr Miloš Lukić, research assistant, Institute for Animal Husbandry, Belgrade - Zemun. 


\section{Poultry housing and nutrition systems}

As a result of the EU directive relating to housing system for layers banning the housing of layers in traditional cages (battery system) in all EU countries from 2012, the alternative solution is needed. System of "deep litter" or system of modified cages where more space is provided for layers are recommended as alternative systems. With the change of housing system also changes in production technology, especially in system of nutrition, are also necessary. Layers reared in alternative systems have more possibilities for moving, they are experiencing more changes in the environment temperature. All of this is affecting the change in necessary amount of food and especially of metabolic energy in diet. Daily needs of layers have increased by $10 \mathrm{~g}$, and in case of those housed in free system with range increase of $15 \mathrm{~g}$ per layer daily of food is necessary. Basically, in case of layers housed in alternative systems consumption of food is increased and feed conversion less favourable. Mortality is also higher in layers housed in alternative systems. The use of alternative systems cost of production of eggs is increased by at least $13 \%$ mainly because of increased cost of food and labour (Harne Van PLM 2003). Over last twenty years efforts are made to improve the housing conditions for layers without affecting production and economical results (Van der Sluis, 2004). Within new nutrition systems of layers more attention is directed to nutrition of layers for production of eggs for hatching. Only correctly fed layer for production of eggs for hatching provides vital chickens with good production results later in fattening (gain of body mass, feed conversion and slaughter results). Feeds and mixtures for nutrition of layers need to be controlled to presence of mycotoxins in order to obtain chickens with desired immunity.

In rearing of fattening chickens also alternative systems are recommended. One of such systems is so called floor system. However, in spite of certain advantages this system has considerable disadvantages. Microbial decomposition of litter leads to air contamination of the chicken coop environment. During production period of fattening the concentrations of ammonium and dust in air increase. All of this has negative effect on production results in chickens (lower gain, unfavourable feed conversion and higher mortality) (Homidan et al. 2003). Therefore, many alternative solutions have been prepared. Alternative systems should enable chickens to move freely. Chicken coops should have optimal temperature which will reduce the consumption of food. Additional ventilation of the chicken coop improves the environment conditions (less dust and ammonium). In spite of mentioned facts alternative systems increase the cost of production by 5 to $10 \%$.

In nutrition of fattening chickens there are certain genetic variations in regard to efficiency of food utilization. Fast growing chickens demand more nutritious matters and energy for maintenance. Selection in regard to growth resulted in increased activity of digestive enzymes (Zhang and Aggrej, 2003). In this way the efficiency of food utilization in chickens of meat type is increased. More energy is used for synthesis of body fats. By selection also feed conversion is improved and chicken is "storing" less energy deposits in form of fat. Recently, new term has been introduced to poultry nutrition - "economically optimal protein level in diet". This is actually level of protein in diet enabling the best economical result (profit). It was established that in nutrition of fattening chickens diet system has proven to be more economical compared to ad libitum nutrition system (Salah, 2003). Namely, it was established that chickens were much calmer without food ad libitum which had positive effect on food utilization and reduction of their maintenance needs.

\section{Animal feed replacers in poultry nutrition}

Ban on use of meat and meat-bone meal in nutrition of domestic animals from December 2000 (EU regulation) also imposed need to find alternative replacers. One of the possible solutions was use of yeast with additional synthetic methionine and organic selenium (Vlahovic et al. 1998). Soy bean meal is good replacer of animal feeds also with addition of synthetic methionine. Optimal level of protein in chicken diet can be provided by increase of share of protein feeds in diet or adding of synthetic amino acids which is often the cheapest and most efficient way. In cases of heat stress, addition of critical amino acids (lysine and methionine) has proven to be very useful especially in regard to feed conversion (Shane and Durham 2003). Producers in European Union who are engaged in organic poultry production and realize somewhat lower production results are attempting to improve them by adding fist limiting amino acid (methionine). In case of layers also betain can be used as additive. Adding of betain to diets for poultry nutrition in organic production process is allowed according to EU regulations. For formulation of poultry diets digestible amino acids are 
used since in this way needs of poultry for mentioned nutritious matters are better satisfied. Investigation carried out by Longe 2003 showed that increase of the level of total digestible amino acids in diets for fattening chickens improved feed conversion. When synthetic amino acids are added to diets for nutrition of fattening chickens the level of metabolic energy must be taken into account - it should be optimal in order to avoid storing of fat tissue in chicken organism. In case of layers, also, input of amino acids must be adjusted to level of energy in diet (Morris 2004). Optimalisation of the amino acid content in diet for poultry will reduce the excretion of ammonium into environment and reduce the pollution of human environment. This can also be achieved by adding of synthetic amino acids to diets containing plant protein feeds. Investigations have demonstrated (Cmiljanić et al. 2003) that by adding synthetic amino acids with probiotics and enzymes production results of poultry can be considerably improved.

\section{Antibiotic replacers}

Ban on use of antibiotics as growth promoters in poultry nutrition resulted in lower production results in "industrial" poultry production. EU has banned antibiotics as growth promoters from June 1st 2001 (Bedford 2000). Negative effect of the ban of application of antibiotics in poultry nutrition was attempted to be alleviated by improved housing conditions, quality of feed (higher digestibility and lower content of anti nutritious matters) and water, management, poultry selection focusing on higher resistance to certain diseases, etc. (Wiebe Van Der Sluis 2004). Beside improved housing conditions antibiotic replacers were introduced such as: probiotics, prebiotics and phytobiotics. Various preparations are prepared consisting of more components. One of the preparations are phytobiotics prepared from natural biologically active substances such as natural grasses, spices combined with essential oils, chelate forms of micro elements (copper, iron, manganese and cobalt) and plant extracts. Alternative solution for antibiotics is also organic acids introduced to water or food which can stop the development of bacteria. One of the solutions is also adding of protein enzymes which provide maximum digestibility and absorption of proteins which means at the same time less protein substrate for bacteria development. Probiotics are also good antibiotic replacers. Addition of probiotic (Paciflor - C) to diets for fattening chickens had positive effect on gain of body mass, feed conversion and health condition of chickens (Cmiljanić et al. 2001). Ted Dickin has made preparation based on essential oils and chelate forms of micro elements. This preparation has proven in practice as successful replacement for antibiotics in poultry nutrition. All of mentioned preparations activate digestion, improve the immune system and have antibacterial effect. Investigation of Sirvydisa et al. (2003) showed that application of phytobiotics intensified protein, fat and carbon hydrate metabolisms in chicken organism. All of this had positive effect on gain of body mass and feed conversion in chickens.

\section{Enzymes in poultry nutrition}

Application of enzymes in poultry nutrition was initiated in the fifties of the last century. With improvement of the technology of production of certain enzymes they became less expensive which contributed to their wider application in poultry nutrition. Today, in Great Britain, in $95 \%$ of produced mixtures for poultry nutrition enzymes are added. Recently enzyme preparations are produced containing two or more enzymes, so called "enzyme cocktails", whose application contributes to realization of better production results. Combination of enzymes as additives contributes significantly to better digestibility of cereals and some protein feeds (sunflower meal, cotton meal, peanut meal, etc.). By application of enzymes the utilization of metabolic energy in poultry is improved (Lin Y.G. 2003). Application of enzyme preparation Enzymix-Ž in fattening of chickens has resulted in improved production results (gain of body mass and feed conversion) (Cmiljanić et al. 1998). By adding two enzyme preparations (Hostazym-C and Enzymix-Ž) to diets for fattening chickens positive effect on gain of body mass, feed conversion and health condition of chickens was achieved (Cmiljanic et al. 2001). It is known fact that sunflower meal is good source of protein but with high share of non starch polysaccharides which have low biological value which is reason why diets containing sunflower meal are supplemented with enzyme preparations. Adding of enzyme preparation "Vegpro" to diets containing sunflower meal has improved significantly feed utilization and viscosity of intestinal content was reduced indicating better utilization of diet. It was concluded that sunflower meal can successfully be included in diets for layers (up to 30\%) if enzyme preparation "Vegpro" was added to diet (Shivaram, Devegowda 2004).

Among enzyme preparations special significance has enzyme phytase. It is known that in plant feeds $70 \%$ of phosphorus is in phytine form which is unavailable and that only $30 \%$ of phosphorus in plant feeds 
can be utilized. Addition of enzyme phytase the utilization of phosphorus from plant feeds can be improved by $30 \%$ (Šefer et al. 2000). The simplest way for application of enzymes is mixing it with other diet components in dry form. However, if food is pelleted and considering how susceptible enzymes are to high temperatures, the application of liquid enzymes is recommended after the pelleting procedure has been completed. Application of enzymes in liquid form demands special equipment which further increases the cost of production process. In case of some enzymes, during pelleting process the enzyme activity is reduced by $24-50 \%$ (Steen 2003). If fats are added to diet than it is better to add enzymes after fats in order to avoid interaction in technological procedure. Recently there have been some efforts in improvement of the quality of enzyme preparations and possibly reduction of their price. When the quality of enzymes is discussed mainly their heat stability, tolerance to $\mathrm{pH}$ of the intestinal content and resistance to proteolytic enzymes is considered. Application of enzymes doesn't improve only the nutritive value of the diet but also at the same time the excretion of undigested remains into environment is reduced, which protects the environment. Beside enzymes also nutrition system can have positive effect on production results. Including of whole (non ground) cereal grain (wheat, barley and triticale) stimulates activity of stomach muscle in poultry which results in better digestibility of diet. Application of pelleted diets in poultry nutrition has positive effect on absorption of nutritious matters and leads to better production results (Vicente-Gauer 2004). Nutrition systems in poultry (intensive and semi intensive) also have effect on production results and quality of poultry products (Cmiljanić et al. 2001).

\title{
NOVI TRENDOVI U ISHRANI ŽIVINE
}

\author{
R. Cmiljanić, Zlatica Pavlovski, Snežana Trenkovski, M. Lukić
}

\section{Rezime}

U radu je dat revijalni prikaz najnovijh trendova u ishrani živine. Prikazan je uticaj sistema držanja $i$ uticaj novih propisa Evropske Unije na tehnologiju ishrane živine.Takodje, je istaknut uticaj novih aditiva (enzima) na proizvodne rezultate i kvalitet živinskih proizvoda (živinskog mesa i jaja). Novi sistemi držanja živine (prelazak sa baterijskog na alternativne sisteme) zahtevaju promenu u sistemu ishrane, a pre svega promenu u sadržaju pojedinih hranljivih materija u obrocima za živinu. Propisi Evropske Unije vezani za zabranu korišćenja antibiotika kao promotora porasta i korišćenje nekih animalnih hraniva (mesno i mesno-koštano brašno) zahtevaju iznalaženje alternativnih rešenja. Umesto antibiotika sve više se koriste: probiotici prebiotici, fitobiotici i mešavine organskih kiselina kao promotora porasta. Kao zamena za animalna proteinska hraniva koriste se: kvasac i sojina sačma uz dodatak sintetičkog metionina i organskog selena. Da bi se poboljšalo iskorišćavanje hranljivih materija iz nekih "grubih" hraniva (žitarice i suncokretova sačma) obrocima za ishranu živine se dodaju enzimski preparati. U ishrani živine se sve više govori o svarljivim aminokiselinama, a sve manje o sirovim proteinima. Pri formulaciji obroka za živinu bolje je koristiti podatke o svarljivim aminokiselinama sadržanim $u$ pojedinim hranivima, jer se na taj način preciznije zadovoljavaju potrebe $u$ ovim hranljivim materijama. U novije vreme se menja forma obroka za ishranu živine. Sve više se koriste peletirane smeše čime se postižu: bolji proizvodni rezultati, manji mortalitet i bolji kvalitet proizvoda. Sve ovo ukazuje da u budućnosti ishranu živine moramo prilagoditi zahtevima potrošača. Potrošač sve više pažnje obraća na kvalitet živinskih proizvoda koji se može obezbediti odgovarajućim sistemom ishrane i držanja.

\section{Literature}

1. BEDFORD M.( 2000 ): Removal of antibiotic growth promoters from poultry diets Implications and strategies to minimise subsequent problem .World's Poultrry Science Journal Vol. 56, No.4,347-365.

2. CMILJANIĆ R., PAVLOVSKI ZLATICA, HOPIĆ S., VLAHOVIĆ MILICA ( 1998 ): The effect of Enzymix-Ž supplementation to diets on body weight gain and feed conversion in fattening chicken. $10^{\text {th }}$ European Poultry conference .Jerusalem Israel, 21-26 June 1998,395-398.

3. CMILJANIĆ R., SRETENOVIĆ LJILJANA, ŽIVKOVIĆ B. ( 1999 ): New trends in the nutrition of farm animals $.5^{\text {th }}$ International Symposium " New trends in breeding farm animals " 6-8 Okt. 1999 Beograd. Biotechnology in Animal Husbandry,15 ( 5-6 ), 61-71. 
4. CMILJANIĆ R., LUKIĆ M., ŠKRBIĆ ZDENKA, TRENKOVSKI SNEŽANA (2001):The effect of Hostazym $-\mathrm{C}$ and Enzymix-Ž supplementation to diets for fattening chickens on gain and feed conversion. Biotechnology in Animal Husbandry. 17 (1-2), 34-39.

5. CMILJANIĆ R., LUKIĆ M.,TRENKOVSKI SNEŽANA .(2001): The effect of Paciflor-C probiotic on gain, feed conversion and mortality of fattening chickens.Biotechnology in Animal Husbandry 17(3-4), 33-38.

6. CMILJANIĆ R., SRETENOVIĆ LJILJANA, TRENKOVSKI SNEŽANA, MARINKOV GORDANA. (2001):Systems of poultry nutrition and their effect on production traits and quality of product . Biotechnology in Animal Husbandry. 17, (5-6),179-185.

7. CMILJANIĆ R., SUPIĆ B., PAVLOVSKI ZLATICA, TRENKOVSKI SNEŽANA, ŽUJOVIĆ M.(2002): Novi propisi Evropske Unije vezano za ishranu domaćih životinja i kvalitet animalnih proizvoda." Savremena poljoprivreda" Vol. 51 (3-4),329-332.

8. CMILJANIĆ R., PAVLOVSKI ZLATICA, TRENKOVSKI SNEŽANA, LUKIĆ M.(2003): New additives in poultry nutrition. $7^{\text {th }}$ International Symposium " Modern Trends in Livestock Production" 30. Sept. to 3-rd Okt. 2003 Belgrade .Biotechnology in Animal Husbandry. Vol. 19 (5-6), 357-362.

9. HORNE VAN PLM .(2003): The impact of layng hen welfare on th competiveness of th E.U. egg industry . World Poultry Vol.19,No.10, 18-19.

10. HOMIDAN AL.A.,ROBERTSON .F.J.,AND PETCHEY. M.A.(2003): Review of the effect of ammonia and dust concentrations on broiler performance. World's Poultry Science Journal .Vol.59, No. 3,340349.

11. LANGE DE L., ROMBOUTS .C.,AND OUDE ELFERINK.G.(2003): Practical application and advantages of using total digestible amino acids and undigestible crude protein to formulate broiler diets. World' s Poultry Science Journal. Vol. 59.,No.4, 447-457.

12. LIU Y.G. (2003): Versatility takes enzymes beyond simple blending.(Adisseo), Asia Pacific Singapure and PA Geraert,Adisseo -France. Feed Tech Vol.7,No.8,25-30.

13. Morris R. T. (2004): Nutrition of chicks and layers. World's Poultry Science Journal Vol.60, No.1,5-12.

14. SUBRATA S., MANDAL I.,BANENRIE, G. C.(1997): Effect of feeding yeasts and antibiotic on the performance of broilers . Indian Journal of Poultry Science . 32(2),126-131.

15. SUPIĆ B., PERIĆ L., MILOŠEVIĆ N., PAVLOVSKI Z., CMILJANIĆ R. (1999): Uticaj ishrane na kvalitet konzumnih jaja. "Savremena poljoprivreda" (1-2),251-257.

16. Salah H.M.Esmail (2003): The economic of feed and feeding of broiler chickens. World's Poultry . Vol 19, No. 8,22-24.

17. SHANE M.S.,DURHAM N.C.(2003): Reducing heat stress problems with heat . World' s Poultry, Vol.19.No. 3, 16-18.

18. SIRVYDIS V.H.,BOBINIENE R.,PRIUDOKINE V.,VENCIUS D.(2003): Phytobiotics and value to broiler feed.World's Poultry. Vol.19, No.1,16-17.

19. SHIVARAM D.A., DEVEGOWDA A. (2004): Effect of enzyme (Vegpro) supplementation to sunflower meal based diets performance of laying hens . XXII World's Poultry Congress. Istanbul 8-13 Sep. 2004, 504-505.

20. STEEN P. (2003): Post pelleting application of liquid enzymes .Feed Tech. Vol. 7 No. 9/10, 20-24.

21. ŠEFER D., LUKIĆ M., CMILJANIĆ R., SINOVEC Z. (2000): Značaj korišćenja enzima u ishrani živine . "Živinarstvo"XXXV , No.5, 61-66.

22. VAN DER SLUIS W. (2004): Floor temperature affects broiler performance. World's Poultry, Vol.20. No.3, 17-18.

23. VICENTE GAUER R. (2004): Drug free diet performance optimised by nutritional programs. World's Poultry .Vol. 20, No.2, 14-16.

24. VLAHOVIĆ MILICA, CMILJANIĆ R. ,PAVLOVSKI ZLATICA, MARINKOV GORDANA (1998): Monocell proteins and seelenium in nutrition of fattening chickes . $10^{\text {th }}$ European Poultry Conference, Jerusalem, Israel, 21-26 Jun 1998, 92-93.

25. WIEBE VAN DER S. (2004): Thoughts structural changes. World's Poultry Vol. 20 No.4,7-8.

26. ZHANG W. AND AGGEREY E. S.(2003): Genetic variation in feed utilization efficiency of meat-type chickens. World's Poultry Science Journal . Vol.59,No.3,328-339. 